\title{
A Humanist Autograph Lost and Found. Mattia Lupi’s Annales Geminianenses
}

\author{
TEDD A. WIMPERIS
}

\begin{abstract}
Mattia Lupi (1380-1468), an early humanist of San Gimignano, was locally famous as the author of a Neo-Latin epic in ten books, Annales Geminianenses, on the history and lore of his native city. This study examines an early witness to this text, shelfmarked ms. 8 in the Wilson Special Collections Library of the University of North Carolina at Chapel Hill. This witness predates the three known manuscript copies of the poem, and has not been recognized by previous scholarship on Lupi and his work. Moreover, comparison of Chapel Hill ms. 8 with known examples of Mattia Lupi's hand reveals this unstudied manuscript to be an autograph text of the Annales Geminianenses, drafted by the author himself between 1463 and 1468.*
\end{abstract}

Mattia Lupi (1380-1468) was an early humanist and poet laureate of the Tuscan city of San Gimignano, famous in his own time as a teacher of grammar and as a collector and copyist of manuscripts. He is equally remembered as the author of a Neo-Latin epic in ten books, titled Annales Geminianenses, that recounts in some 12,500 lines of dactylic hexameter the local history and legends of his native city, reaching from San Gimignano's ancient foundations up to the mid-fifteenth century, the time of the poem's composition. ${ }^{1}$ Save for a series of excerpts published

* I am grateful to the editors of this journal and the anonymous reviewers for their helpful suggestions; I thank also the staff of the Rare Book Collection of Wilson Library in Chapel Hill, and especially Robert G. Babcock, who supported this study throughout its development.

${ }^{1}$ The most detailed source on Lupi's life and work remains a series of three articles published in the early twentieth century: G. Traversari, "Di Mattia Lupi (1380-1468) e de' suoi Annales Geminianenses", Miscellanea storica della Valdelsa 11.1 (1903), 8-27; 11.2 (1904), 108-128; 12.2 (1904), 117-136. The first installment in the series treats Lupi's career; the second focuses on his Annales Geminianenses; the third is an appendix of primary sources for his biography. I hereafter refer to these separate articles as Traversari 1903, 1904a, and 1904b. See also the more recent work of M.C. Davies, "The Senator and the Schoolmaster. Friends of Leonardo Bruni Aretino", Humanistica Lovaniensia 33 (1984), 1-22; F. Cirilli, "Mattia Lupi", in Dizionario biografico degli italiani, vol. 66 (Roma, 2006), 597-599; and the entry on Lupi in J.L. Flood, Poets Laureate in the Holy Roman Empire. A Bio-Bibliographical Handbook, vol. 3 (New York, NY, 2006), 12191221. 
in 1793, Lupi's epic has never been printed, and previous scholarship has assumed that the transmission of the text is limited to three manuscript copies produced between the sixteenth and the eighteenth centuries. This article brings to light a fourth and much earlier witness to this text, the manuscript shelfmarked ms. 8 in the Hanes Collection of Manuscripts in the Louis Round Wilson Special Collections Library of the University of North Carolina at Chapel Hill (henceforth W). ${ }^{2}$ My research on this unstudied manuscript indicates that $\mathbf{W}$ is in fact an autograph text of the Annales Geminianenses, drafted in Mattia Lupi's own hand between 1463 and 1468 and replete with his autograph corrections and suppletions.

The Annales Geminianenses is a singular production of early humanist Latin literature, unique in its structure, encyclopedic scope, and diverse literary influences. The work begins with an extended proem in which the author announces his intention to recount the illustrious history of his native land (Patriae $[\ldots]$ gesta, 1$)$, and extolls the recent Historiae Florentini populi of Leonardo Bruni, Lupi's teacher and mentor, as the primary model for his own history in verse (23-28). ${ }^{3}$ The first two books narrate San Gimignano's legendary founding in the first century BCE by the brothers Mucius and Silvius; into this narrative Lupi inserts a long episode, modeled on the Vergilian prophecy of Roman glory in Aeneid 6, in which a prophet on the banks of the river Elsa recites for the brothers the history of the world from Creation through the future Roman Empire. The remaining books alternate between a condensed annalistic structure and developed narrative sequences to review events in Tuscany through antique, medieval, and contemporary times, with occasional biographical and autobiographical digressions and descriptions of local lore. Book 8 includes a prolonged excursus on ancient and modern poets, culminating in the careers of Dante, Petrarch, Boccaccio, Salutati, and Bruni. The poem ends abruptly in its tenth book with the anticipation of a new crusade against the Turks in the 1460s, the decade of the author's death.

\footnotetext{
${ }^{2}$ Chapel Hill, Wilson Special Collections Library, Rare Book Collection, ms. Hanes 8 .

3 The first fifty lines of Lupi's proem are included among the printed excerpts published by Angelo Maria Bandini in 1793: A.M. Bandini, Bibliotheca Leopoldina Laurentiana sive Supplementum ad catalogum codicum Graecorum, Latinorum, Italicorum, etc. Bibliothecae Laurentianae, vol. 3 (Firenze, 1793), 503-518. I discuss Bandini's role in the poem's transmission in the second half of this study.
} 
Although critical consensus has deemed Lupi's magnum opus an ambitious failure with little artistic merit, it was long respected as an authoritative regional history, and represents a distinctive contribution to contemporary Latin literature that lies at the intersection of various poetic and historiographical traditions. ${ }^{4}$ Its poetic idiom and diction belong squarely to the epic tradition; at the same time, its historical subject matter engages the Latin didactic tradition that also employed hexameter verse, as well as the genre of poetry and oratory written in praise of cities (laudes urbium) that flourished in Italy during the Renaissance. ${ }^{5}$ But it lacks the conventional devices, characters, and setpieces of classical epic - save for the markedly Vergilian styling of the foundation myth in books 1 and 2 - and stands quite apart from the many contemporary Latin epics composed to celebrate the deeds of local cities and princes. ${ }^{6}$ As a work of historiography, the Annales is written in conscious emulation of Bruni's patriotic history of Florence, a work indebted to the ancient models of Livy, Thucydides, and Polybius; but it also has clear affinities with late medieval urban historiography, especially vernacular verse chronicles produced in Italy. ${ }^{7}$

Wilson Library's manuscript of this historiographical epic first arrived in North Carolina in the private collection of Rev. Aaron Burtis Hunter (1854-1933), an Episcopal clergyman and educator who, from 1891 to 1916, served as principal of St. Augustine's Normal School and

${ }^{4}$ Davies 1984 (as in n. 1), 9, summarizes the main critical reactions to the Annales; Traversari 1904a (as in n. 1), 121-122, singles out its disjointed organization and tedious literary style. The poem's reception in the fifteenth through eighteenth centuries is addressed further below.

${ }^{5}$ On Latin epic, didactic, and laudes urbium in the Renaissance, see the summaries in J. IJsewijn, D. Sacré, Companion to Neo-Latin Studies. Part II: Literary, Linguistic, Philological, and Editorial Questions (Leuven, 1998), 24-50; more examples of historical didactic poems are adduced by V. Moul, "Didactic Poetry", in Ead. (ed.), A Guide to NeoLatin Literature (Cambridge - New York, NY, 2017), 180-199, with further references.

${ }^{6}$ On this genre of Latin epic, see esp. K. Lippincott, "The Neo-Latin Historical Epics of the North Italian courts. An Examination of 'Courtly Culture' in the Fifteenth Century", Renaissance Studies 3 (1989), 415-428; a broader overview of Neo-Latin epic, with additional bibliography, is P. Gwynne, "Epic", in Moul 2017 (as in n. 5), 200-220.

${ }^{7}$ Bruni's approach to historiography is treated comprehensively by G. Ianziti, Writing History in Renaissance Italy. Leonardo Bruni and the Uses of the Past (Cambridge, MA, 2012). An overview of the urban historiographical traditions that preceded the works of Bruni and Lupi is supplied by A. Vasina, "Medieval Urban Historiography in Western Europe (1100-1500)", in D.M. Deliyannis (ed.), Historiography in the Middle Ages (Leiden, 2003), 317-352. Traversari 1904a (as in n. 1), 126, identifies Italian verse chronicles as the closest single model for the Annales Geminianenses; his discussion of the poem's sources and influences extends from 122-127. 
Collegiate Institute in Raleigh. Hunter was a prolific collector of incunabula and manuscripts, many of which he acquired in Italy during his tenure as rector of St. James Episcopal Church in Florence, beginning in $1920 .^{8}$ It was probably during his years in Florence that Hunter purchased the manuscript of Lupi's poem, which still bears evidence of its sale: in the upper left corner of the verso of the front flyleaf, written in pencil, is the price of 500-, presumably in lire, a sum consistent with Hunter's other recorded purchases. ${ }^{9}$ From the time of his return to Raleigh in 1927 until his death in 1933, Hunter sold and donated large portions of his collection to the University of North Carolina in nearby Chapel Hill. The library probably acquired $\mathbf{W}$ - then numbered 451 in Hunter's private collection - in October-November 1929, when Hunter offered 100 of his early manuscripts as a gift to the university. ${ }^{10}$

In 1931, the university library loaned some of its manuscripts, including $\mathbf{W}$, to the Library of Congress for review by the bibliographer Seymour de Ricci for inclusion in his Census of Medieval and Renaissance Manuscripts in the United States and Canada. The second volume of the Census, published in 1937, contains De Ricci's entry for the manuscript:

Matteo Ciaccheri [or Mathias Lupius], Annales Sangeminianenses in Latin verse (Me movet optantem patriae describere gesta...). Paper (XVth c.), $245 \mathrm{ff}$. $(22 \times 14 \mathrm{~cm})$. Written in Italy. Modern vellum binding. Rev. Aaron Burtis Hunter coll., n. 451. ${ }^{11}$

${ }^{8}$ For Hunter's biography, see esp. C.M. Bennington, “Aaron Burtis Hunter", in W.S. Powell (ed.), Dictionary of North Carolina Biography, vol. 3 (Chapel Hill, NC, 1988), 234-235; and J.D. Eaton, "A History and Evaluation of the Hanes Collection in the Louis Round Wilson Library" (unpublished master's thesis, University of North Carolina, 1957), 6-21. Eaton's thesis also details the library's acquisition of Hunter's collection.

${ }^{9}$ Hunter's private diaries, which now belong to the Aaron Burtis Hunter Collection in the North Carolina State Archives, record many of his purchases of manuscripts and incunabula during these years; the manuscript of the Annales Geminianenses does not appear among these lists.

${ }^{10}$ Cf. Eaton 1957 (as in n. 8), 18. Correspondence between Hunter and the university librarians about this and other transactions is preserved in the Rare Book Collection Records in Wilson Library.

${ }^{11}$ S. de Ricci, Census of Medieval and Renaissance Manuscripts in the United States and Canada, vol. 2 (New York, NY, 1937), 1908. A note attached to the front flyleaf of W supplies the additional record, "Notes by Seymour di Ricci [sic] for Library of Congress Manuscripts Catalogue, 1931." 
De Ricci's attribution of authorship of the Annales to Matteo Ciaccheri is erroneous; the alternative "Mathias Lupius", the name he would have seen on the binding of the manuscript and at the top of $\mathrm{f}$. $1 \mathrm{r}$ at the poem's opening, is the correct ascription. ${ }^{12}$ More recently, P.O. Kristeller provided a newer description of $\mathbf{W}$ in the fifth volume of Iter Italicum:

Ms. 8. Cart. XV. 232 numbered and some blank fols. Semigothic script. Cf. De Ricci II, p. 1908. (Annales Sangeminianenses), a Latin poem in ten books, inc. Me movet optantem patrie describere gesta. Attributed in a late hand (s. XVI-XVII) to Matthias Lupius poeta laureatus. ${ }^{13}$

Besides the two descriptions of De Ricci and Kristeller, I have found no further published work on $\mathbf{W}$. Neither of these cataloguers recognized the manuscript as the author's autograph, and scholarship on Lupi published since its acquisition by the University of North Carolina appears unaware of the manuscript's existence.

W contains 245 folia, arranged in 22 quires of ten or twelve leaves. The text is written on sheets of paper measuring $22 \times 14 \mathrm{~cm}$. Every leaf is ruled in dry point, and the ruled space for text on each page measures $16 \times 10 \mathrm{~cm}$, providing for a consistent 26 verses per page. The poem runs from f. $1 \mathrm{r}$ to $\mathrm{f} .232 \mathrm{v}$; the remaining sheets in the manuscript are fully ruled, but unnumbered and mostly blank. ${ }^{14}$ The modern vellum binding, measuring $23 \mathrm{~cm}$ high by $15 \mathrm{~cm}$ wide and a muted yellow in color, predates Hunter's purchase of the volume. Author, text, and date are identified on the binding in bold black letters: Matthias Lupius, Annales Geminianenses, MS. Sec. XV. The 245 folia of the manuscript are bookended by two flyleaves attached to the modern binding, onto the first of which is pasted De Ricci's description from 1931. The flyleaves

\footnotetext{
12 Manetto Ciaccheri (the name "Matteo" is a later corruption) was once identified as the author of another historical poem on San Gimignano, Cronachetta di San Gemignano, composed in terza rima in 1355; but Ciaccheri's authorship has been disputed, and the Cronachetta is now attributed to Agnolo di Vanni Coppi. See P. Stoppelli, "Manetto Ciaccheri", in Dizionario biografico degli italiani, vol. 25 (Roma, 1981), 79-80; and L. Gentile, "L'autore della Cronachetta di San Gemignano in terza rima", Il Propugnatore 1 (1888), 127-131.

13 P.O. Kristeller, Iter Italicum, vol. 5 (London - Leiden, 1990), 239.

14 The only writing on these unfinished leaves is on f. $235 \mathrm{r}$, where there is calligraphic script in black ink, floridly executed; at least some of the words are Latin, and appear to be written as an exercise in penmanship rather than a coherent phrase or title. This page does not seem connected to Lupi's poem in any way, though the writing may be the work of one of the manuscript's later annotators (see below).
} 
and pastedowns are decorated with a floral pattern. A bookplate on the front pastedown bears Hunter's name and insignia.

Four pages of $\mathbf{W}$ (f. $1 \mathrm{r}, 44 \mathrm{v}, 72 \mathrm{v}, 228 \mathrm{v}$ ) are reproduced with this article in Plates 1-4. The entire text of the epic poem is written by a single hand in a semigothic script dated by both De Ricci and Kristeller to the fifteenth century. ${ }^{15}$ Almost all emendations and additions of verses to the main text, which occur frequently throughout the manuscript, are written in this same hand, as are most of the catchwords and some of the dates supplied in the margins to accompany the poem's historical narrative. In addition to this main scribe, to be identified as Lupi himself, there are four distinct marginal annotators, unique in their hands and ink color, who have provided Latin glosses, running commentary, headings for each book, foliation in the upper right corner of each recto, occasional retouching of the original text, and more historical dates to complement Lupi's material. One of these anonymous annotators provided the attribution above the opening of the poem to Matthias Lupius poeta laureatus. None of the annotations was made later than the late sixteenth or early seventeenth century. ${ }^{16}$

The opening of each of the Annales' ten books is marked by a short break in the text and a large rubricated initial that begins the first verse of the new book. ${ }^{17}$ One of the annotators added titles - liber secundus, liber tertius, etc. - for books 2-10, inserted into the space between the end of one book and the beginning of the next. A different annotator also included a running title at the top of the recto of each leaf that tracks the number of the book. It is unclear whether Lupi himself or an associate was responsible for executing the stylized initials that begin almost every new book.

The poem appears to be incomplete, as book 10 is markedly shorter than the nine previous installments: while the other nine books range in length from 969 to 1636 verses, this final book totals a mere 254. More-

15 Kristeller 1990 (as in n. 13), 239, identifies the hand as semigothic; see also A. Derolez, The Palaeography of Gothic Manuscript Books. From the Twelfth to the Early Sixteenth Century (Cambridge, 2003), 176-180, on Italian "Gotico-Antiqua" and related scripts, with further bibliography.

16 The marginal notes by the four annotators of $\mathbf{W}$ were transcribed into the first apograph of Lupi's original, which was produced no later than 1619; I discuss this manuscript further below.

${ }^{17}$ Book 1: f. 1r-28v; book 2: $28 \mathrm{v}-47 \mathrm{v}$; book 3: $47 \mathrm{v}-76$ r; book 4: $76 \mathrm{v}-102 \mathrm{v}$; book 5: $102 \mathrm{v}-132 \mathrm{v}$; book 6: 133r-151v; book 7: 151r-192r; book 8: 192v-202r; book 9: 202r-228v; book 10: $228 \mathrm{v}-232 \mathrm{v}$. 
over, the tenth book is the only one lacking a rubricated initial in $\mathbf{W}$. Where it begins on f. $228 \mathrm{v}$, the usual square space on the page has been allotted to accommodate the large initial, but the space is left blank. Instead, the first letter of the first line is written in the usual semigothic script, leaving the verse intact despite the missing initial. The thirteen blank leaves, fully pricked and ruled in dry point, that continue after the text breaks off on f. $232 \mathrm{v}$ may also signify that the poem's composition ended earlier than the author had intended.

The identification of this manuscript as Mattia Lupi's autograph relies on evidence drawn not only from its material detail, but also from Lupi's other scholarly activities. His career as a priest and teacher of grammar brought him into contact with other famous humanists of his time, including Leonardo Bruni, from whom he received an early education in the classics, as well as Niccolò Niccoli and Enea Silvio Piccolomini (later Pope Pius II). ${ }^{18}$ His encyclopedic historical epic, which he began in 1463 and continued writing until his death five years later, attests to his erudition and literary ambitions, but arguably his greatest contribution to scholarship in his day was his assembly of an impressive library of classical authors and other scholarly texts. After decades of copying, commissioning, and purchasing manuscripts, he donated this collection to his native city of San Gimignano, an arrangement negotiated and fulfilled between 1449 and 1460. ${ }^{19}$ After Lupi's death in 1468, his manuscripts were transferred to a new wing adjoining the Collegiata di Santa Maria Assunta, where they remained until 1568. In that year, Duke Cosimo I of Florence claimed for himself many of the books belonging to the Collegiata, and the majority of Lupi's library was transferred to Florence. Several of Lupi's manuscripts now reside in the Biblioteca Medicea Laurenziana, and continue to be identified among its holdings; a remainder left by the Duke are now in the Biblioteca Comunale di San Gimignano.

${ }^{18}$ On Lupi's relationships with these and other contemporaries, see esp. Davies 1984 (as in n. 1), 12-21; and Traversari 1903 (as in n. 1), 12-25. Lupi also appears in several epigrams of Antonio Beccadelli's Hermaphroditus (1425), and Leonardo Dati composed a poem in elegiac couplets ad Lupium poetam celebrating Lupi's laureation in the early 1460s; these are reproduced in Traversari 1904b (as in n. 1), 126-129.

${ }^{19}$ On this donation, see G. Fioravanti, "Librerie e lettori a San Gimignano nel ' 400. Onofrio Coppi e Mattia Lupi", Interpres 18 (1999), 58-73; and E. Casanova, "La libreria di M. Mattia Lupi in San Gimignano", Rivista delle biblioteche e degli archivi 8 (1897), 64-68; also Davies 1984 (as in n. 1), 9-10. 
Lupi's volumes are recognizable by his distinctive hand, colophons that identify him as the copyist, and his coat of arms. ${ }^{20}$ Of the manuscripts in the Biblioteca Laurenziana, Lupi copied the majority of Silius Italicus' hexameter epic Punica (ms. Plut. 37.18, f. 39r-45v, 56v-192v), Donatus' commentary on Terence (ms. Plut. 53.8), and all but the last fourteen leaves of a volume of Eutropius, Florus, and Hegesippus (ms. Plut. 67.18). He also owned a copy of Boethius (ms. Plut. 77.3), for which he supplied f. 47r-v in his own hand to replace a missing leaf, and into whose colophon he inserted his own name. Lupi's arms, an escutcheon illustrated with the image of a wolf, appear in a copy of Ovid's Fasti and Catullus (ms. Plut. 36.23, f. 1r) drafted by his collaborator Bartolomeo Nerucci, as well as a thirteenth-century copy of Macrobius and Apuleius (ms. Plut. 51.9, f. 1r). ${ }^{21}$ His manuscripts in the Biblioteca Comunale di San Gimignano include ms. 19 (Villedieu's Doctrinale) and ms. 30 (Francesco da Buti's commentary on Horace's Ars poetica), as well as parts of ms. 27, a miscellany containing a copy, in Lupi's hand, of a recommendation letter originally written on his behalf by Leonardo Bruni.

Mattia Lupi's distinctive hand, well known from these several manuscripts, conclusively identifies $\mathbf{W}$ as his autograph text of the Annales Geminianenses. As another example of a Latin hexameter poem copied by Lupi, his volume of Silius Italicus in the Biblioteca Laurenziana, ms. Plut. 37.18, completed in January 1453 and signed with his name in the colophon (f. 192r), offers the closest comparison with the manuscript in Chapel Hill. I supply two images of this manuscript (Plates 5-6) for comparison with those of $\mathbf{W}$. The pages of both manuscripts exhibit the same appearance and arrangement: in spacing, the thickness of the letters, and the enlarged capital letter beginning each verse, the two texts are recognizably the work of the same hand. Breaks between books of the poem show the same allotment of space for a large stylized initial beginning each new incipit. Lupi uses a small but consistent repertoire

\footnotetext{
${ }^{20}$ Lupi's manuscripts are discussed in Fioravanti 1999 (as in n. 19), 67-69; and Davies 1984 (as in n. 1), 10-12.

21 On ms. Plut. 36.23, see also A.C. de la Mare, "Humanistic Script. The First Ten Years", in F. Krafft, D. Wuttke (ed.), Das Verhältnis der Humanisten zum Buch (Boppard, 1977), 89-110, at 98-100. Ms. Plut. 51.9 and ms. Plut. 54.24, another Apuleius manuscript that probably belonged to Lupi, are closely examined in J.H. Gaisser, The Fortunes of Apuleius and the Golden Ass. A Study in Transmission and Reception (Princeton, NJ, 2008), 138-144. On Bartolomeo Nerucci, see also Davies 1984 (as in n. 1), 11 n. 58.
} 
of abbreviations in each text, though he deploys them much more freely in $\mathbf{W}$ than in his copy of Silius; these include the 3 -shaped enclitic -que and final $-m$, the Tironian $e$, contracted $n$ or $m$, and abbreviated quam and final -rum, with some others appearing less frequently. His $s t$ and $c t$ are ligatured. In both manuscripts, he often writes two dashes in the immediate left margin to mark divisions and transitions in the text.

Close inspection of individual letter forms further confirms that both manuscripts were written by the same hand. The bottom of the $g$ swings out to the right before cutting left with a tapering horizontal stroke, and its closed bowl on the baseline comes to a point on the right side. Final $s$ appears in its short, rounded form. Letters $b$ and $d$ have vertical ascenders, and, with $l$, are spatulated at the top. The right foot of $h$ curves back to the left and tapers downward; the right foot of $n$ drifts out to the right. The capital letters that begin each new verse are also identical in both manuscripts. The shaft of capital $I$ is wedged at the top, coming to a point on the left side, below which another point protrudes from the shaft; the bottom of the letter tapers off to the left on or just below the baseline. The left foot of capital $A$ ends in a horizontal serif, and the right foot slopes gently downward to rest on the baseline. The asymmetrical capital $U$ begins with a longer stroke on the left side. Capital $D$ has an angular shape that comes to two points on the left side; the bottom of the letter usually dips only once to touch the baseline.

The author's corrections and suppletions to the text are abundant, and uniformly written in his own hand. His active editing is well illustrated on f. 228v (Plate 4), where he variously supplements, deletes, adjusts, and corrects his draft across the surface of the page. Extra verses are squeezed into the spaces between lines, and entire passages are written out in the margins of the page, linked to their proper place in the main text with a series of symbols. Words accidently omitted from specific lines are inserted with a caret. Sometimes Lupi chooses to replace a word by writing in an alternative directly above it, as, for instance, he does near the bottom of f. $228 \mathrm{v}$, where he underlines inprimis and supplies admissi in smaller script overhead. In the first copy of the Annales produced from the autograph, and then in subsequent copies, the rough emendations that cover the pages of $\mathbf{W}$ have been cleanly integrated, according to Lupi's authorial indications, into the text of the poem. 
This evidence from the manuscript's physical description and contents confirms the identity of $\mathbf{W}$ as an original draft of Lupi's Annales Geminianenses. The author's familiar arms even make a subtle appearance on $\mathrm{f}$. 1r (Plate 1): behind the large ornamental $M$ that begins the poem, the illustration of a wolf on a circular crest is still visible, its mouth painted with a stroke of red ink. When Guido Traversari published his series of articles on Lupi and the Annales in 1903-1904, he began his installment on the epic poem by lamenting the apparent loss of Lupi's original text: "Diciamo prima di tutto che degli Annales Geminianenses non abbiamo l'originale, che con buone ragioni possiamo dire perduto." 22 In an attached footnote, Traversari explains his unsuccessful efforts to locate the autograph with the help of the Lupi family and the current prefect of the Biblioteca Laurenziana, Niccolò Anziani. Only now, over a century later, has the autograph again come to light.

$$
* * *
$$

Although completion of the Annales was prevented by Lupi's death in 1468 - this would account for the rather abrupt end of the enormous poem some 250 lines into its tenth book - it went on to enjoy a healthy reception among later generations of Sangimignanese and Florentine scholars, as a thorough compendium of local history, the magnum opus of a home-grown poet laureate, and a specimen of humanist Latin literature of the Quattrocento. The rich annotation of Lupi's autograph during the 150 years after his death suggests this continuing interest, as the attentive addition of headings, dates, and glosses served to render the exhaustive epic more accessible to its readers. The poem is cited extensively by two later historians of San Gimignano, Giovanni Vincenzio Coppi and Luigi Pecori, who published their histories in 1695 and 1853 , respectively. ${ }^{23}$

The most telling witnesses of the poem's later value are the three known copies of the Annales produced between the sixteenth and eighteenth centuries. ${ }^{24}$ The first apograph (N) of Lupi's original was

22 Traversari 1904a (as in n. 1), 108.

${ }^{23}$ G.V. Coppi, Annali, memorie, ed huomini illustri di Sangimignano (Firenze, 1695); L. Pecori, Storia della terra di San Gimignano (Firenze, 1853).

${ }^{24}$ Although I have not conducted a full comparison of these three copies with $\mathbf{W}$, they appear to reproduce Lupi's original text faithfully and accurately; the copyists make no adjustments or additions to the poem except for those directed by the author's own correc- 
produced in the late sixteenth or early seventeenth century, and now resides in the Biblioteca Nazionale Centrale di Firenze, numbered II.II.12 in the Fondo Nazionale. The codex containing the Annales Geminianenses also includes other brief texts in prose and verse pertaining to the history of San Gimignano; these were copied or composed between 1615 and 1619 by Paolo Emilio Mainardi, a descendant of one of the city's prominent families and the apparent compiler of the whole codex. $^{25}$ Lupi's poem comprises the majority of the volume, filling 245 of its 295 leaves, and was written by at least two copyists, neither of whom is Mainardi. ${ }^{26}$ The hand responsible for the earlier portions of the poem belongs to one of the main annotators of Lupi's autograph; this annotator wrote the attribution to Matthias Lupius poeta laureatus at the top of $\mathrm{f}$. $1 \mathrm{r}$ in $\mathbf{W}$, an ascription he provides again in $\mathbf{N}$ above the opening lines of the Annales.

$\mathbf{N}$ was acquired by the former Biblioteca Magliabechiana in 1804 under the library's prefect, Vincenzo Follini (1759-1836). According to the detailed record of the volume's contents and provenance attached to the beginning of $\mathbf{N}$ by Follini, the copy of Lupi's Annales was transcribed "ex auctoris adversariis ut videtur, ac proinde archetypo". ${ }^{27}$ Follini supplies no further information about the manuscript's exemplar, except to point out that $\mathbf{N}$ is not itself the autograph, as it dates from a full century after the poet's death. ${ }^{28}$ Internal evidence from $\mathbf{N}$ also supports the judgment that this manuscript was copied from Mattia Lupi's original: while diverse hands composed the annotations and commentary to the Annales in the pages of $\mathbf{W}$, virtually all marginalia

tions and suppletions in the autograph. It is clear that the first copy, ms. Naz. II.II.12 in the Biblioteca Nazionale Centrale di Firenze (N), was produced from the autograph $\mathbf{W}$, but I have not determined whether the two later copies, Holkham ms. $430(\mathbf{H})$ and San Gimignano ms. $72(\mathbf{G})$, were produced from $\mathbf{N}$ or directly from $\mathbf{W}$.

${ }^{25}$ Mainardi identifies himself on f. $251 \mathrm{r}-\mathrm{v}$ and $289 \mathrm{r}$; he was also responsible for a brief index of the poem's ten books and a biographical note on Lupi found in the blank pages that precede the beginning of the Annales (f. XIr and XIIv, respectively). The other texts are listed in Mazzatinti's entry on $\mathbf{N}$ in his inventory of manuscripts in the Biblioteca Nazionale: G. Mazzatinti, Inventari dei manoscritti delle biblioteche d'Italia, vol. 8 (Forlì, 1898), 136-137.

${ }^{26}$ I have inspected reproductions of $\mathrm{f}$. $1 \mathrm{r}-11 \mathrm{r}$ and $239 \mathrm{v}-245 \mathrm{r}$ of the manuscript, and each of these segments is written in a different hand. Even more hands may be responsible for the intervening text.

${ }^{27}$ N, f. IVr: "From the author's notes, it appears, and thus from an original text."

${ }^{28}$ Follini alleges that the historian Coppi had wrongly identified this manuscript as Lupi's original; I address this claim further below. 
found in the autograph were fully transcribed into $\mathbf{N}$ along with the poem itself, uniformly in the hands of the copyists of the new text.

Follini's introduction records the manuscript's ownership from its production until its sale to the Biblioteca Magliabechiana. Paolo Emilio Mainardi is identified as the earliest owner of $\mathbf{N}$ (f. VIIIr-v); it is unclear whether he had a hand in producing the copy of Lupi's Annales that precedes his additional texts on San Gimignano, or only obtained that manuscript after its completion. Sometime during the seventeenth century, ownership of the codex passed to the Lupi family, beginning with Francesco Lupi and his heirs, then Giovanni Vincenzio Lupi, who is named (as "Joannis") in a small annotation on a blank page preceding the beginning of the Annales (f. XIIr). In the years leading up to 1793, Angelo Maria Bandini (1726-1803), the prefect of the Biblioteca Laurenziana, was loaned $\mathbf{N}$ by Paolo Lupi for inclusion in the supplement to Bandini's catalogue of Latin and Greek codices in the library. Bandini includes in his entry on the Annales Geminianenses a brief biography of Lupi and several printed excerpts from the epic; to date, the selections published by Bandini represent the only printed edition of the poem. ${ }^{29}$ After the loan to Bandini, the codex remained in the hands of Paolo Lupi's descendants, Giovanni Battista Lupi and Orazio Lupi, until 1804. In that year they sold it to a certain Giuseppe Canovai, from whom it was purchased by Follini for the Biblioteca Magliabechiana on 10 September 1804. The codex has been in the library ever since, where it was recorded in Mazzatinti's 1898 inventory of the manuscripts in the modern Biblioteca Nazionale.

Another copy of the Annales Geminianenses, the second produced according to its date, resides in Norfolk, England, in the library of Holkham Hall, ms. 430 (H). The first Earl of Leicester, Thomas Coke (16971759), was an avid bibliophile who assembled much of this massive private library over the course of his life, beginning with a Grand Tour of Europe as a young man (1712-1718) during which he acquired several hundred manuscripts and incunabula from the continent. In 1932,

${ }^{29}$ Bandini 1793 (as in n. 3), 503-518. Bandini was familiar with Mattia Lupi and his work through the manuscripts from Lupi's former library that belonged to the Biblioteca Laurenziana, and refers to those volumes in his preface to the excerpts from the Annales Geminianenses. Bandini's use of $\mathbf{N}$ as the source of his printed passages is confirmed by his citations for each excerpt: the page numbers he cites as the location of his selected passages correspond with the foliation of $\mathbf{N}$. With each printed excerpt, he also reproduces the marginal commentary that accompanied the text in the manuscript. 
Seymour de Ricci published a handlist of Holkham's manuscripts, in which the copy of Lupi's poem is numbered ms. 430 and identified as belonging to the collection of Domenico Ferrari. ${ }^{30}$ Ferrari (1685-1744) was a learned Neapolitan who had emigrated to England and become tutor to the young Thomas Coke during the Grand Tour. After their return to England, Ferrari became a fellow at St. John's College, Cambridge, and continued to manage the organization and acquisitions of Coke's library. During his years in service to the Earl, he assembled a sizeable library of his own, consisting of nearly 200 volumes. Upon his death, a portion of his books was bequeathed to Holkham Library; this included, it appears, his copy of the Annales Geminianenses.

The Holkham copy of Lupi's Annales contains 416 leaves, and bears the description Historie antiche di Mattia Lupi da San Gimignano poeta laureato libri dieci. ${ }^{31}$ De Ricci and Kristeller both date it to the seventeenth century. $\mathbf{H}$ was probably unknown to Traversari, who seems unaware of its existence in his detailed articles on Lupi and the Annales, and it is only mentioned in a footnote by Davies. ${ }^{32}$ It almost certainly originated in Italy, probably Florence, a major source of purchases for Coke and Ferrari during and after their Grand Tour. Literature on Italian history and culture occupies much of the Holkham collection, and it may have been this general interest that inspired the acquisition of Lupi's historical epic on San Gimignano. ${ }^{33}$

The latest manuscript of the Annales (G) resides in San Gimignano at the city's Biblioteca Comunale, shelfmarked ms. 72 (formerly A.IV.6) in Gino Garosi's 1972 catalogue of the library's manuscripts. ${ }^{34}$ This copy, written on 189 leaves, can be precisely dated to 1701 thanks to a dedicatory epistle at the beginning of the text, which also reveals the circumstances of its production: the manuscript was commissioned by Giovanni

30 S. de Ricci, A Handlist of Manuscripts in the Library of the Earl of Leicester at Holkham Hall (Oxford, 1932), 37. On Holkham Library, see esp. S. Reynolds, A Catalogue of Manuscripts in the Library at Holkham Hall. Volume 1, Manuscripts from Italy to 1500. Part 1, Shelfmarks 1-399 (Turnhout, 2015), 1-29; 13-16 discuss Domenico Ferrari.

${ }^{31}$ P.O. Kristeller, Iter Italicum, vol. 4 (London - Leiden, 1989), 44.

32 Davies 1984 (as in n. 1), 9 n. 48.

33 The forthcoming installment of Suzanne Reynold's Catalogue of the Manuscripts in the Library at Holkham Hall (Volume 1, Part 2) will include $\mathbf{H}$, and may reveal more about the manuscript's provenance.

${ }^{34}$ San Gimignano, Biblioteca Comunale, ms. 72. See G. Garosi, Inventari dei manoscritti delle biblioteche d'Italia, vol. 88 (Firenze, 1972), 211; and P.O. Kristeller, Iter Italicum, vol. 6 (London - Leiden, 1992), 209. 
Vincenzio Coppi, the historian of San Gimignano, and prepared for him by the author of the dedication, one Orazio Masini, praesbiter Florentinus. ${ }^{35}$ Ownership of the manuscript later passed from Coppi to Alessandro Checcucci (1803-1879), a Sangimignanese scholar and priest of the Piarist order; a dry stamp on f. 1r identifies $\mathbf{G}$ as part of his collection. In 1872, Checcucci founded San Gimignano's current municipal library with a donation of some 2,700 volumes to the city, at which time his copy of the Annales Geminianenses may have been transferred to its current home. Unlike Lupi's autograph and its two earlier copies now in the Biblioteca Nazionale di Firenze and Holkham Library, this manuscript only contains the first nine books of the epic, omitting the unfinished tenth.

The 1701 manuscript in the Biblioteca Comunale di San Gimignano is the last known copy of Mattia Lupi's poem. More remains to be said, however, about the historian Coppi's involvement with Lupi's Annales, for his use of the poem in composing his 1695 Annali, memorie, ed huomini illustri di Sangimignano proffers some evidence of the autograph manuscript's whereabouts after 1468. Vincenzo Follini, in his record of provenance for $\mathbf{N}$, asserts that Coppi had believed (erroneously, he claims) that the autograph copy was preserved in his own time by the heirs of Francesco Lupi:

Codex huiusmodi idem prorsus est quem Coppius, Uomini illustri Sangimignanesi pag. 195, memorat velut autographum penes haeredes Francisci Lupi Doctoris exstantem. Sed Coppius hallucinatur dum codicem originalem putat, qui post integrum circiter saeculum a Matthiae Lupii obitu scriptus videtur. ${ }^{36}$

Coppi's alleged identification of $\mathbf{N}$ as Mattia Lupi's autograph rests on his description, on the page cited by Follini, of the Annales Geminianenses as "l'eroico poema de' fatti della sua patria, molto ammirabile,

35 The epistle (on f. 1r of G) is printed in Traversari 1904a (as in n. 1), 108 n. 2. Coppi's known use of Lupi's autograph (explained below) heightens the probability that $\mathbf{W}$ was the exemplar of his commissioned copy.

${ }^{36} \mathbf{N}$, f. IVr-v: "A volume of this description is the very one which Coppi [...] records, as if it were the autograph, as belonging to the heirs of Doctor Francesco Lupi. But Coppi errs in thinking that this volume is the original, as it seems to have been written roughly a full century after Mattia Lupi's death." Follini's citation refers to the second volume of Coppi's history, which contains the section titled "Uomini illustri Sangimignanesi". 
che originalmente si conserva dagli eredi del già sig. dottore Francesco Lupi". ${ }^{37}$

Follini assumes that the manuscript used by the historian was $\mathbf{N}$, and that when Coppi refers to the original text as belonging to Francesco Lupi's heirs, he is suggesting, incorrectly, that $\mathbf{N}$ was Mattia Lupi's autograph. But Follini is mistaken in both assumptions; Coppi, rather, was correct in claiming that the text he knew was Mattia Lupi's original, for we can be sure that the manuscript he consulted was not $\mathbf{N}$ (as Follini takes for granted), but $\mathbf{W}$. His use of the autograph rather than the apograph $\mathbf{N}$ is confirmed by a citation in his history of a passage of the Annales Geminianenses where Lupi describes his education under Leonardo Bruni. ${ }^{38}$ Coppi cites the passage in Annales book 3 as beginning on folium 72 of Lupi's text (Plate 3); this citation agrees with the foliation of $\mathbf{W}$, the autograph copy. In $\mathbf{N}$, this passage occurs on folium 85 , as Bandini faithfully cites in his printed reproduction. ${ }^{39}$

The revelation that Francesco Lupi and his immediate heirs possessed the autograph also corroborates a piece of evidence originally supplied by Traversari, who had found a brief reference to the Annales Geminianenses in a series of bibliographical notes from the Florentine scholar and senator Carlo Strozzi (1587-1670). ${ }^{40}$ Of the Annales, Strozzi writes, "Le Historie di Mattia Lupi: l'originale lo ha domino Francesco Lupi in carattere antico, e una copia bene scritta l'ha la comunità di San Gimignano." Strozzi's identification of Francesco's manuscript as the autograph is strengthened by its description as "in carattere antico", a judgment more apt for Mattia Lupi's fifteenth-century semigothic original than the more recent $\mathbf{N}$.

The evidence from Coppi and Strozzi that Francesco Lupi and his heirs owned the autograph during their lifetimes, further affirmed by Coppi's citation of the autograph text as his source, allow us to locate this manuscript in San Gimignano at the very end of the seventeenth century, when Coppi published his history. The autograph had probably resided there until that time, preserved by the author's family. But what transpired between 1695 and the early 1920s, when Aaron Burtis Hunter

${ }^{37}$ Coppi 1695 (as in n. 24), vol. 2, 195.

${ }^{38}$ Ibid.

${ }^{39}$ Bandini 1793 (as in n. 3), 507.

40 These notes of Strozzi are preserved within the miscellany Firenze, Biblioteca Nazionale Centrale, ms. Magl. VIII.1491, no. 69 ("Tre ricordi al Sig. Carlo Strozzi"); cf. Traversari 1904a (as in n. 1), 108 n. 1. 
purchased it, remains a matter of speculation. By the first years of the twentieth century, when Traversari attempted to locate the original draft of the Annales, the Lupi family had no recollection of its whereabouts. It seems most probable that the autograph was sold by members of the Lupi family sometime during the intervening 200 years, much as Giovanni Battista and Orazio Lupi sold N to Giuseppe Canovai in 1804. If more evidence comes to light, the full narrative of this manuscript's history prior to its arrival in the United States may become clearer still.

The recovery of Mattia Lupi's autograph restores to modern scholarship a singular witness to the life of this early humanist, and opens new perspectives on both the reception of his Annales Geminianenses and the broader production of Latin literature in the Quattrocento. Lupi has long been appreciated as a patron of humanistic learning for the rich library of manuscripts, many copied by his own hand, with which he endowed his native city. Chapel Hill ms. 8 now joins these artifacts of Lupi's career, a new and invaluable addition to his legacy that testifies to his artistic pursuits, learning, and civic spirit, and captures in its diligent additions and emendations the studious process of the author at work.

\author{
Elon University \\ twimperis@elon.edu
}




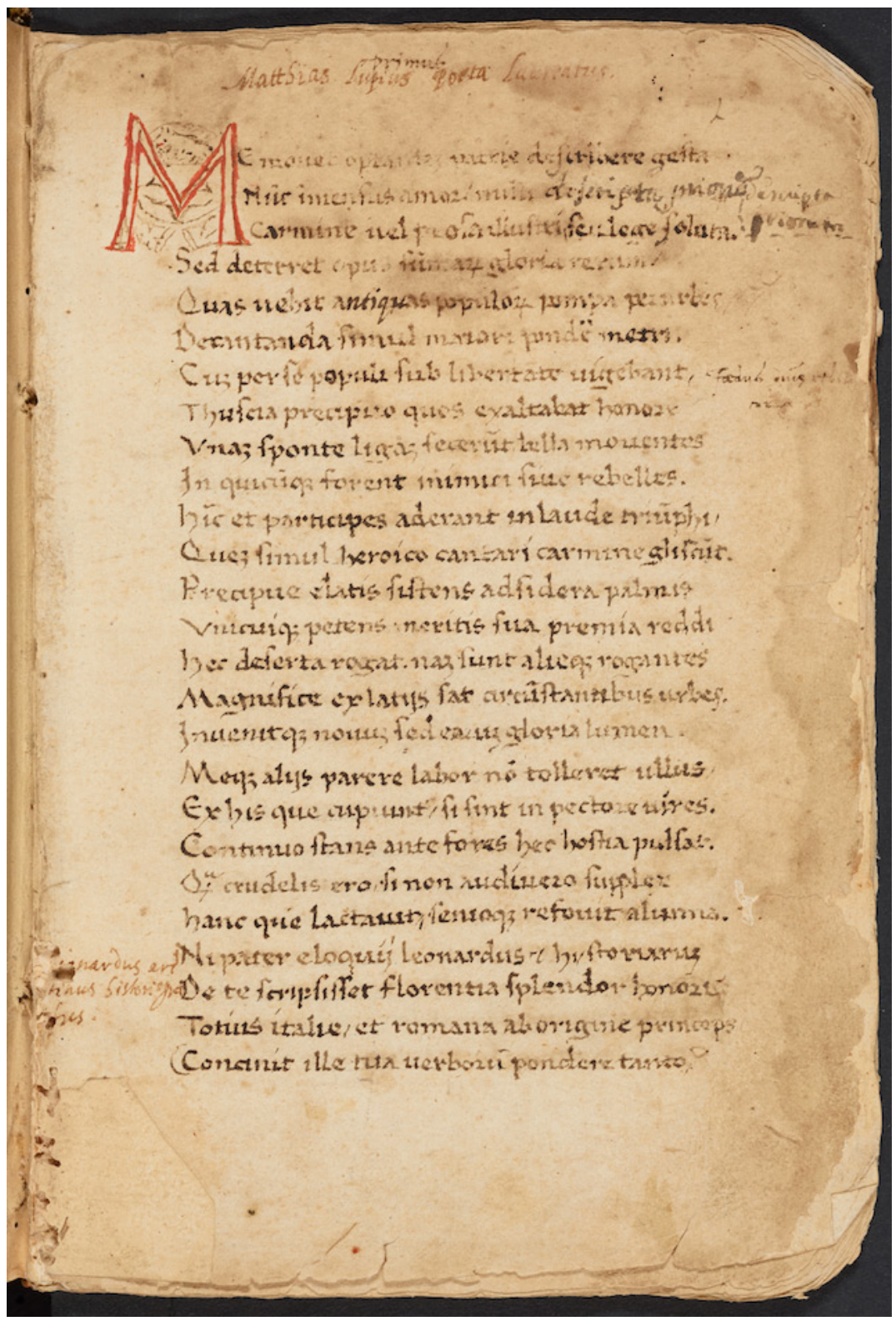

Plate 1: University of North Carolina at Chapel Hill, Wilson Special Collections Library, Rare Book Collection, ms. Hanes 8, f. 1r. 


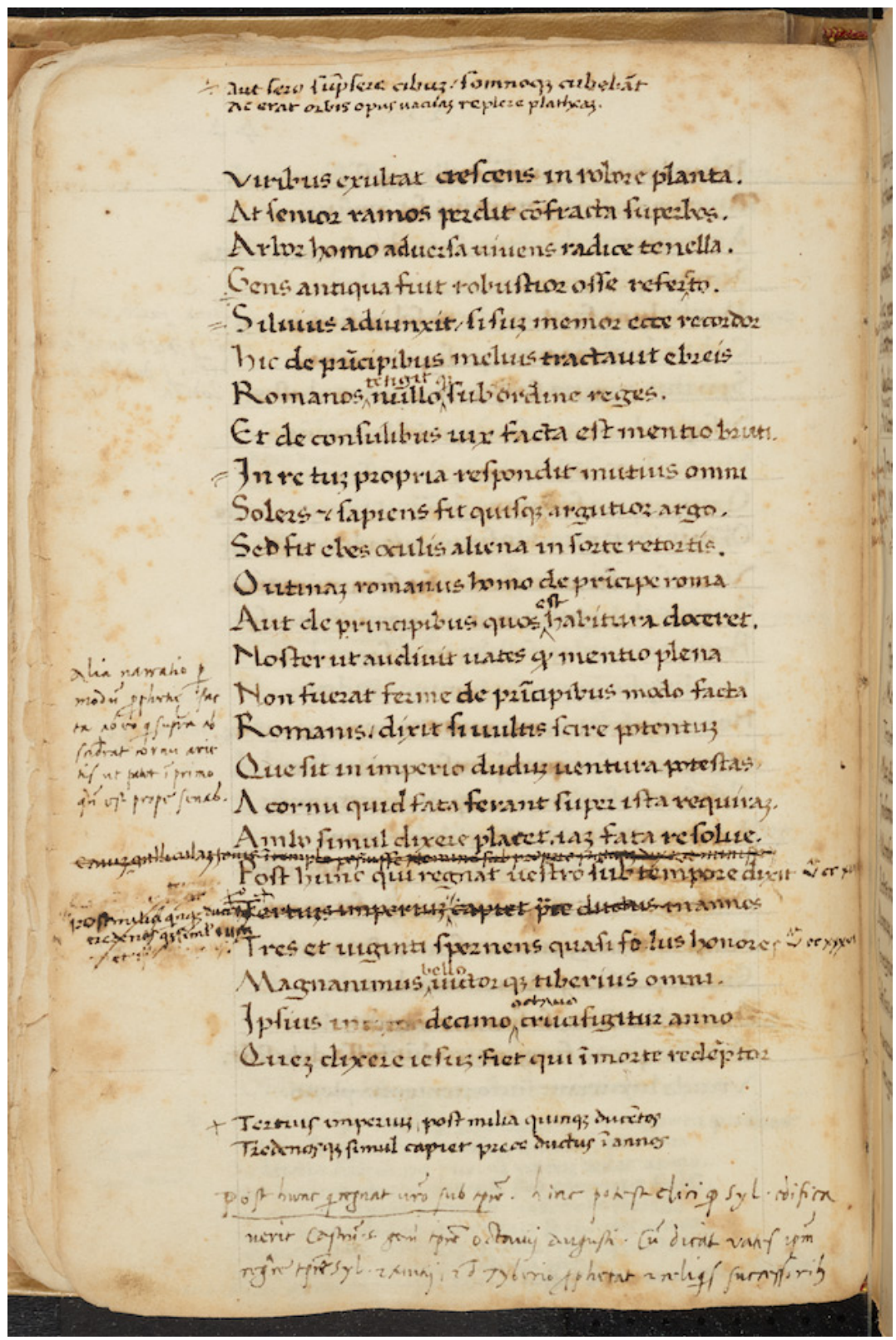

Plate 2: University of North Carolina at Chapel Hill, Wilson Special Collections Library, Rare Book Collection, ms. Hanes 8, f. 44v. 


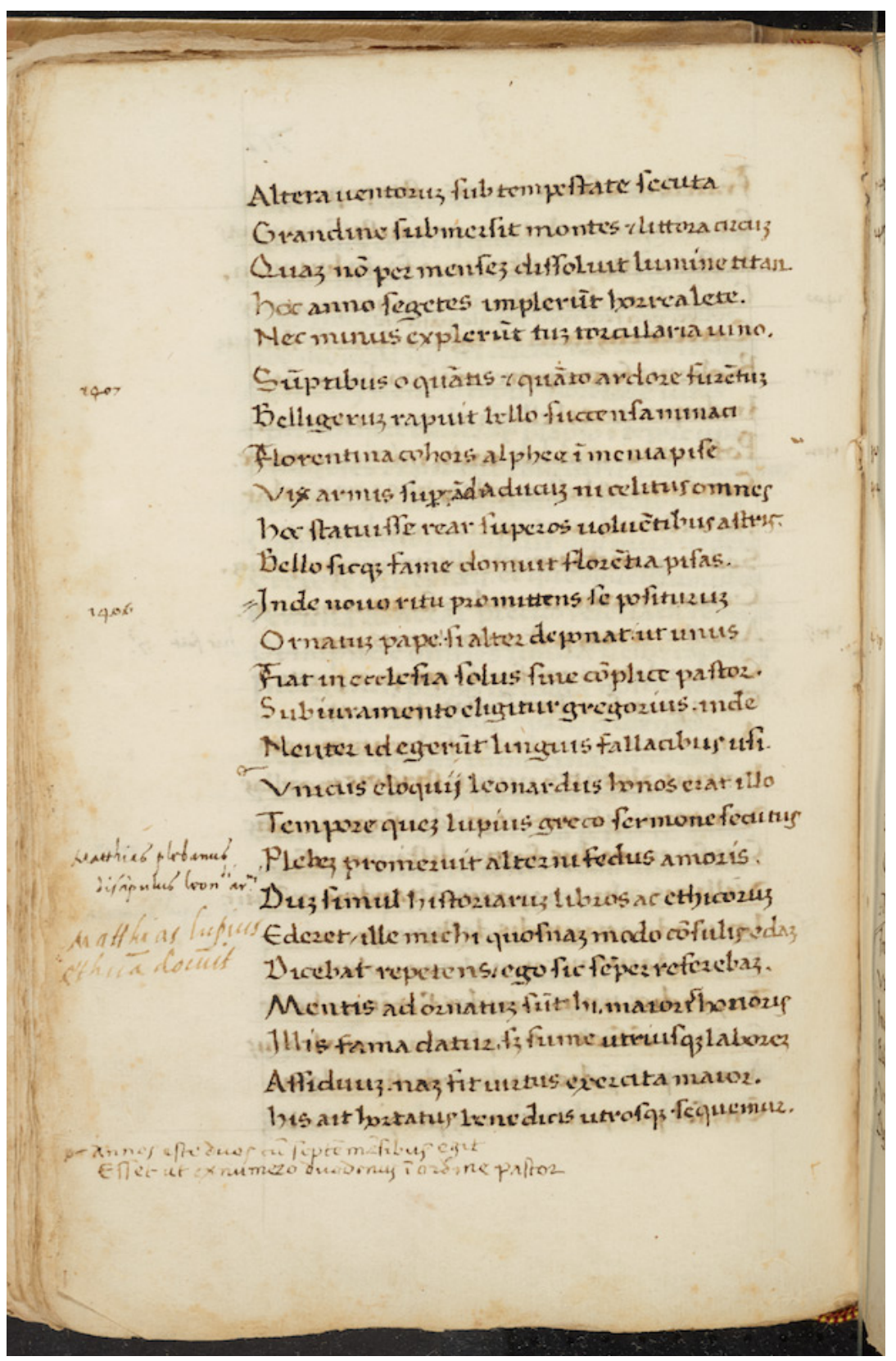

Plate 3: University of North Carolina at Chapel Hill, Wilson Special Collections Library, Rare Book Collection, ms. Hanes 8, f. 72v. Humanistica Lovaniensia 67.1 (2018), 47-68 


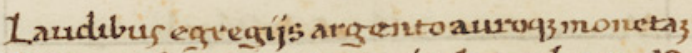

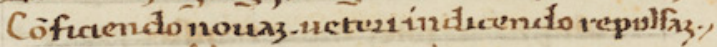
Giber DEcimis.

Extrimii da frine dens coponsze carmen Ydibus octobzis inituz, ourctibus annif

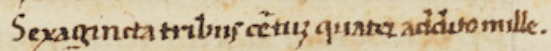

$146_{3}$

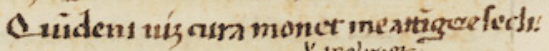
Sed nö prima redur numezo feticiozetas.

Mille eteníz quendas patres wixese per annor.

Octuaguna modo.talm z doloz occupat archus.

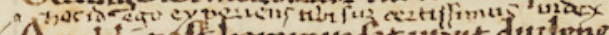

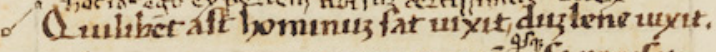

Vuscze nonmenuat. moztez no 1 ifferecufet.

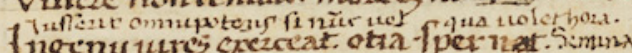

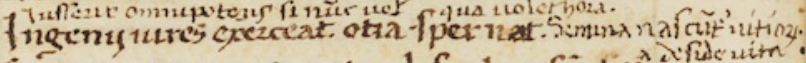

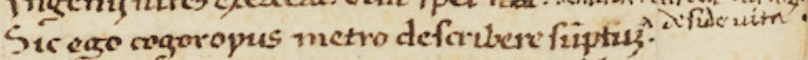

Quos inter medus fors hor inclufent addazi

Vt folcocafis inemozi noutcate colender.

Meforo qua famess pezztezint forrtus aras

Pacisi ut inapiaz de te mea patria piomuz,

Solus ut untritezet teto difandeze fectín

Confuluit rules te uendete pronfug agellor.

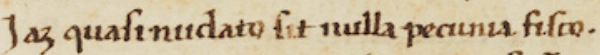

d.wo periyt usigiluz modo magnificèta pasruz

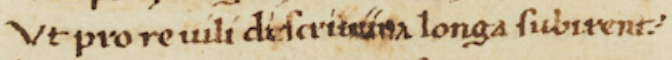

Intea at emplazes oviturcoitentio prima

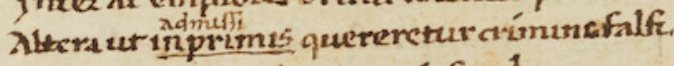

Poft inutrafoj fust nunuzdafood da paztes.

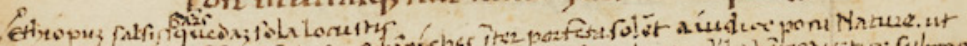

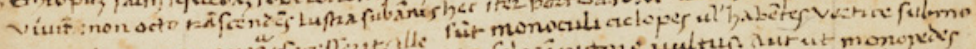

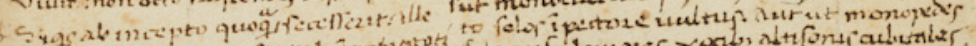

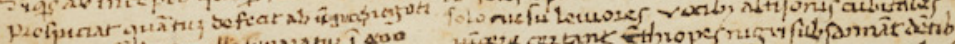

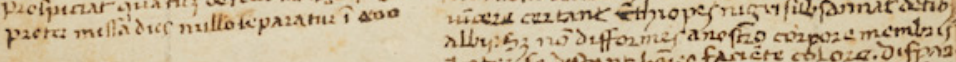

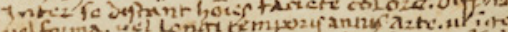
iel folma.

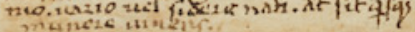

Plate 4: University of North Carolina at Chapel Hill,

Wilson Special Collections Library, Rare Book Collection, ms. Hanes 8, f. 228v. 


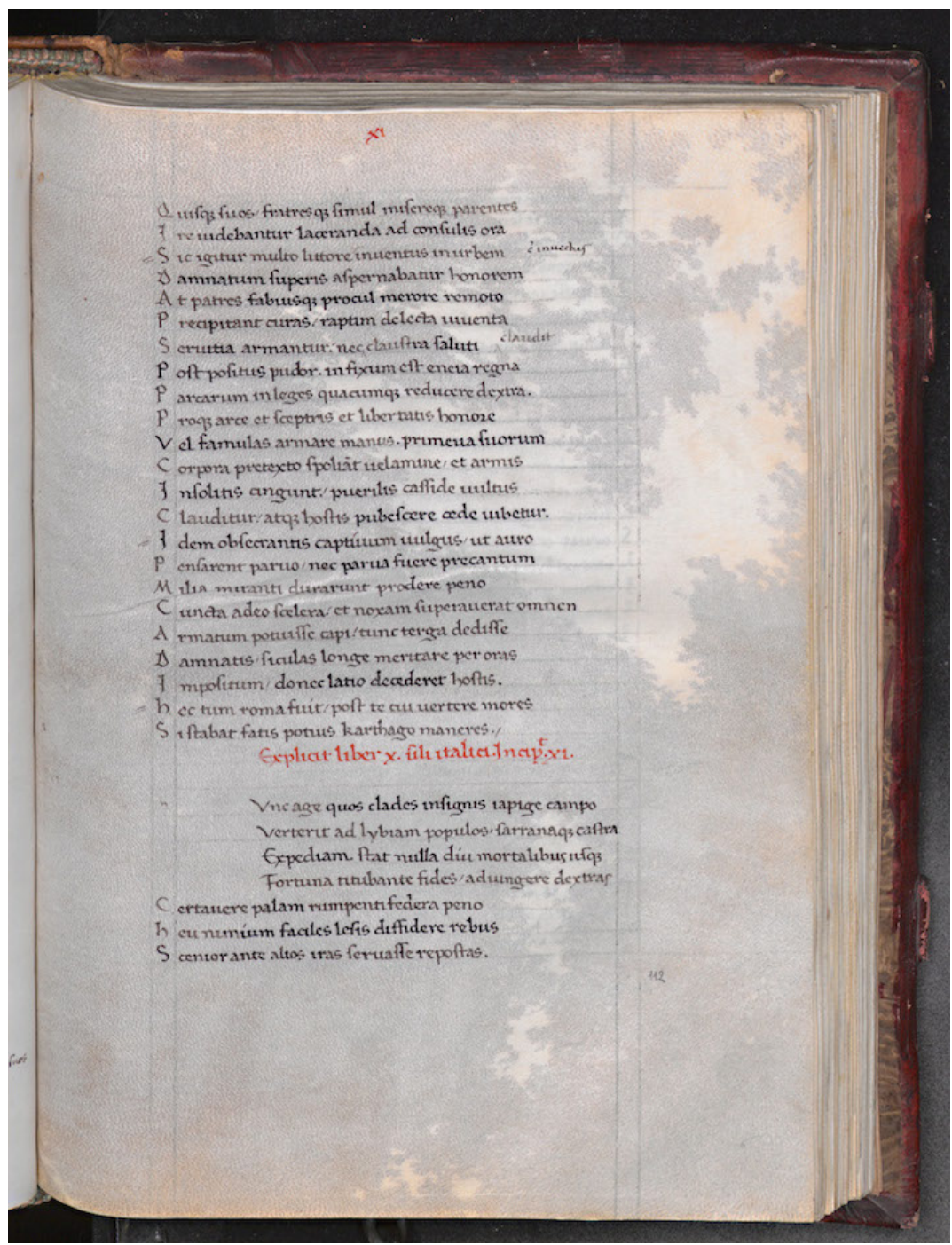

Plate 5: Firenze, Biblioteca Medicea Laurenziana, ms. Plut. 37.18, f. 112r. Su concessione del Ministero dei beni e delle attività culturali e del turismo. È vietata ogni ulteriore riproduzione con qualsiasi mezzo. 


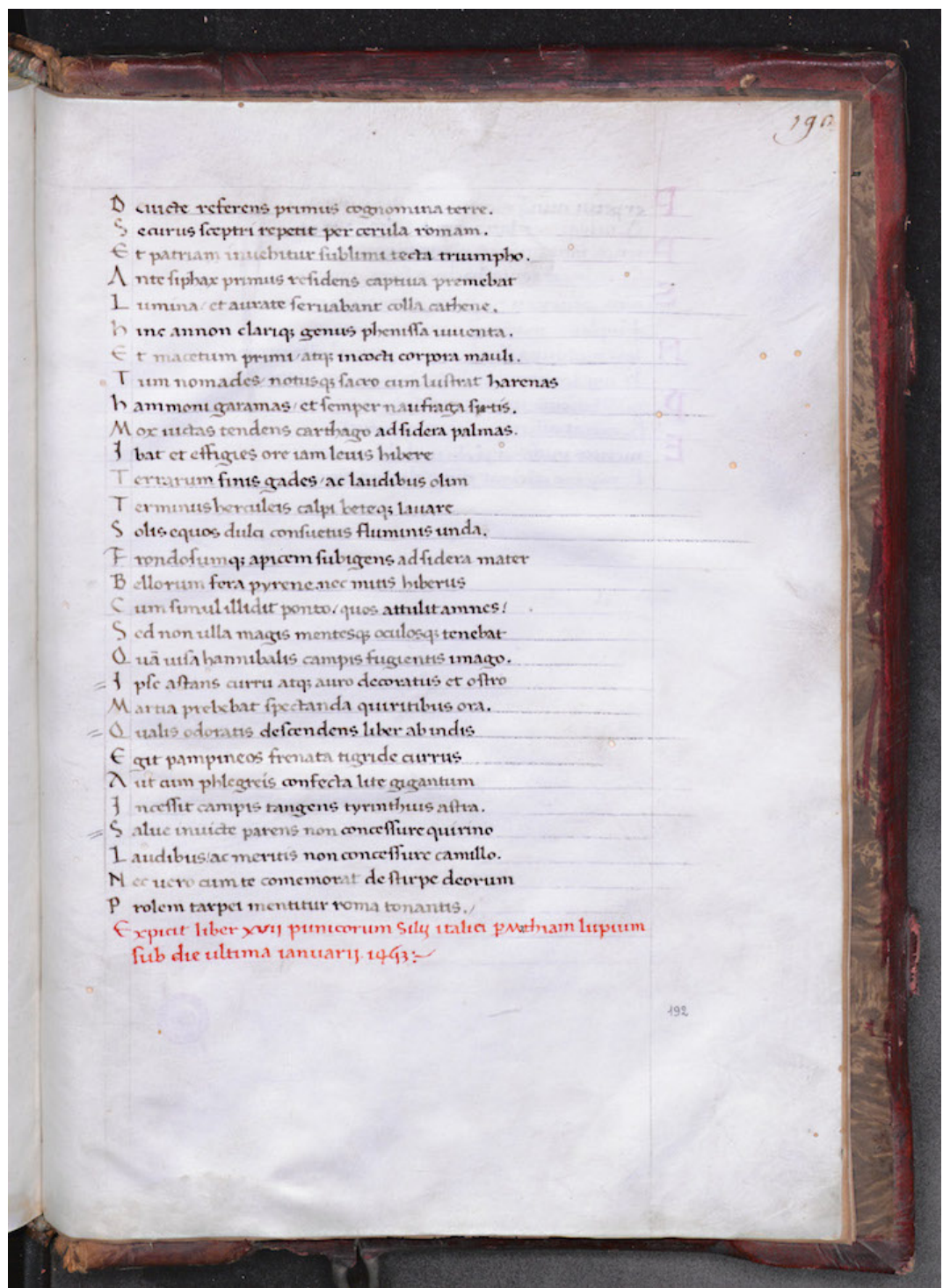

Plate 6: Firenze, Biblioteca Medicea Laurenziana, ms. Plut. 37.18, f. 192r.

Su concessione del Ministero dei beni e delle attività culturali e del turismo. È vietata ogni ulteriore riproduzione con qualsiasi mezzo. 